\title{
Chromatographic separation of some cell wall polysaccharide-degrading enzymes of the sheep rumen Ciliate Epidinium caudatum
}

\author{
F Clayet, J Senaud, J Bohatier \\ URA CNRS 138, Protistologie, Complexe Scientifique des Cézeaux, \\ 63177 Aubière Cedex, France
}

Vegetal cell wall-degrading enzyme activities have been described in the rumen ciliate Epidinium caudatum (Coleman, 1985), and recently detected from protozoal axenic extracts (Bonhomme, 1988). The present study gives preliminary results for the separation and a comparative biochemical characterization of the enzymic equipment in rumen ciliate protozoa.

To purify enzymes of $E$ caudatum involved in cell wall degradation, we carried out gel filtration chromatography on cell-free extracts obtained by sonication, according to the cellulolytic and hemicellulolytic bacteria decontaminating method of Bonhomme (1988).

Ten different activities were identified in fractions eluted by phosphate buffer $(\mathrm{pH} \mathrm{6)}$, by spectrophotometry, using

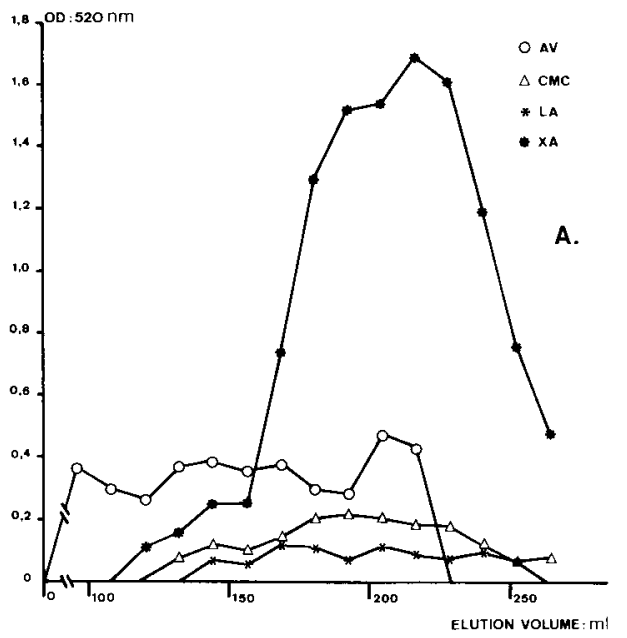

either reducing sugar measurement for avicellase (AV), carboxymethylcellulase (CMC), laminarinase (LA) and xylanase (XA) (fig 1A), or paranitrophenol release from pNP-glycosides for arabinosidase $(A R)$, cellobiosidase (CE), fucosidase (FU), galactosidase (GA), glucosidase (GL) and xylosidase (XO) (fig 1B). CMCase activity was localized in 2 proteins with $M_{\mathrm{r}} 23$ and $45 \mathrm{kDa}$ calculated by SDS-Page. Glycoside hydrolase activities are related to higher molecular weight proteins (>100 kDa).

This proper enzymic equipment allows us to conclude that Epidinium caudatum is a true cellulolytic microorganism.

Bonhomme A (1988) Jpn J Vet Sci 50, 543547

Coleman GS (1985) J Agric Sci 104, 349-360

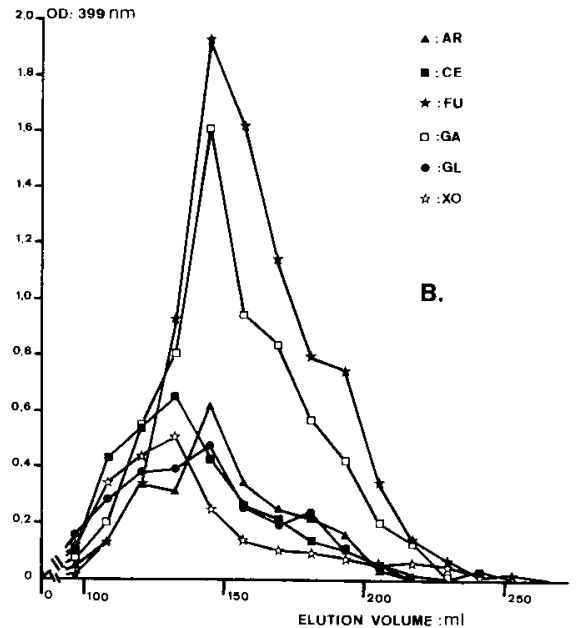

Fig 1A, 1B. Separation by gel filtration on Ultrogel ACA 34 of major cellulolytic and hemicellulolytic enzymes of Epidinium caudatum isolated from sheep rumen content. 